\title{
Kaynaştırma Ortamlarında Ailelere Yönelik Eğitsel ve Psikolojik Hizmetler
}

\begin{abstract}
Yeşim GÜLEÇ ASLAN*
Öz

Özel gereksinimli bireyin akranlarıyla birlikte kaynaştırma ortamlarında eğitim alması, özel eğitimin temel hedeflerinden birisidir. Başarılı bir kaynaştırma uygulamasındaysa okul-aile işbirliği oldukça önemlidir. Ailenin kaynaştırma uygulamalarına katılımı sağlandığında, aile ve özel gereksinimli birey kaynaştırma uygulamasından en üst düzeyde faydalanabilmektedir. Ailenin aktif katılımının sağlanabilmesi için, aileye eğitsel ve psikolojik hizmetler sunulmalıdır. Bu makalede çocuğu kaynaştırma ortamında eğitim alan ailelere yönelik eğitsel ve psikolojik hizmetler incelenmiştir.
\end{abstract}

Anahtar Kelimeler: Aile, Ailelere Sunulan Hizmetler, Kaynaştırma, Özel Eğitim.

\section{Educational and Psychological Services for Parents in Inclusive Education Environments}

\begin{abstract}
One of the main objectives of special education is to enable individuals with special needs to receive education in inclusive education environments with their peers. Parent-teacher collaboration is quite important for a successful inclusive education practice. Maximum benefit can be provided for individuals with special needs and their parents when parents' involvement in inclusive practices is ensured. Educational and psychological services should be offered to parents to assure their active involvement in inclusive practices. This article deals with the educational and psychological services offered to parents having children receiving education in inclusive education environments.
\end{abstract}

Keywords: Parents, Services Offered to Parents, Inclusive Education, Special Education.

\footnotetext{
* Doç. Dr., İstanbul Medeniyet Üniversitesitesi, Eğitim Bilimleri Fakültesi, Özel Eğitim Bölümü, yesim.gulec@medeniyet.edu.tr
} 


\section{GİRIŞ}

Özel gereksinimli bireyin akranlarıla birlikte kaynaştırma ortamlarında eğitim alması, öz

el eğitimin temel hedeflerinden birisidir. Kaynaştırma uygulamalarının başarılı bir şekilde sürdürülebilmesiyle, bu bireyler tüm gelişim alanlarında önemli ilerlemeler göstermektedir. Ayrıca, kaynaştırma ortamlarındaki eğitimler aracilığıyla toplumsal ortamlara uyum sağlama ve olabildiğince bağımsız yaşama doğrultusunda da önemli kazanımlar elde edebilmektedirler (Hallahan ve Kaufmann, 2009; Hornby, 2014; Turnbull, Turnbull, Wehmeyer ve Shogren, 2013). Kaynaştırma uygulamalarının başarılı olması için dikkat edilmesi gereken çeşitli etmenler söz konusudur. Öğretmenlerin bilgi ve becerilerinin artması, normal gelişim gösteren ve kaynaştırma uygulamasındaki öğrenciler ile ailelerinin sürece hazırlanması, öğretimsel uyarlamaların yapılması ve fiziksel ortamın düzenlenmesi bu etmenlerden birkaçıdır (Hornby, 2014; Obiakor, Harris, Mutua, Rotatori ve Algozzine, 2012). Kaynaştırma uygulamasındaki öğrencilerin aileleriyle işbirliği yapılarak bu ailelerin kaynaştırma uygulamalarına katılımının sağlanması ise, kaynaştırma uygulamalarının başarıyla yürütülmesindeki en önemli etmenlerden bir tanesidir.

Başta ebeveynleri olmak üzere tüm aile bireyleri çocuğun tıbbi geçmişi, günlük alışkanlıkları, problemleri ve ihtiyaçları gibi konularda bilgi almak için başvurulabilecek temel kaynaklardır (Cavkaytar ve Özen, 2010; Turnbull vd., 2013; Walmsley ve Mannan, 2009). Bu doğrultuda, çocuğun aynı zamanda ilk eğitimcisi olan ebeveynlerin ve diğer aile üyelerinin kaynaştırma uygulamalarına katılımı, çocuğun gelişimi ve sunulan eğitsel hizmetlerin etkililiği için oldukça önemlidir (Elkins, VanKraayenoord ve Jobling, 2003; Odluyurt ve Batu, 2012; Özen, 2008; Sileo ve Prater, 2012; Smith, Gartin, Murdick ve Hilton, 2006; Sucuoğlu ve Kargın, 2010; Turnbull vd., 2013; Varol, 2007). Ayrica, kaynaştırma ortamlarında eğitim almaya başlayan bir çocuğun içinde bulunduğu okul sistemi aileyi, aile de okulu çeşitli şekillerde etkilemektedir. Çünkü, çeşitli kuramlarda da belirtildiği üzere aile, çocuk ve toplum arasında karşlıklı bir etkileşim söz konusudur (Kaner, 2009; Turnbull vd., 2013). Bu etkileşimi açılayan temel kuramlardan bir tanesi olan ekolojik sistem kuramına göre (Bronfenbrenner, 1979, 1986), aileyi ve çocuğu etkileyen çeşitli iç içe geçmiş sistemler söz konusudur. Çocuğun gelişimi üzerindeki en önemli kişiler olan ailesi, öğretmenleri ve arkadaşları mikrosistemi oluşturmaktadır. Bu mikrosistemler arasındaki etkileşimler ise mezosistemi oluşturmaktadır. Örneğin, aile ve öğretmenler, aile ve çocuk arasındaki etkileşimler mezosistemde yer almaktadır ve bu etkileşimler karşılıklı olarak birbirlerini etkilemektedirler. Örneğin, ebeveynlerin boşanması çocuğu, okul sistemindeki herhangi bir sorun aileyi olumsuz yönde etkileyebilmektedir. Diğer sistemler olan ekzosistem, makrosistem ve kronosistem ise, çocuğun dolaylı olarak etkileyen sosyo-kültürel unsurları kapsayan sistemleri ve tüm sistemlerin birbiriyle etkileşimlerini kapsamaktadır. Örneğin, yerel yönetimler, ailenin içinde yaşadığı toplumun kültürel özellikleri ve ekonomik kriz gibi etmenler bu sistemler arasındadır (Ahioğlu-Lindberg, 2012; Bronfenbrenner, 1979, 1986; Kaner, 2009). Diğer bir temel kuram ise aile sistemleri kuramidır (Kaner, 2009; Turnbull vd., 2013; Wehman, 1998). Bu kurama göre aile kendi içinde belirli kuralları ve işlevleri olan bir sistemdir. Aile üyelerinin arasında sürekli bir etkileşim bulunmaktadır ve aile içindeki herhangi bir durum, ailedeki tüm bireyleri etkilemektedir. Dolayısıyla, özel gereksinimli bireye hizmet sunan uzmanlar sunacakları hizmetleri aile bireylerinin özellikleri, aile içindeki etkileşim, ailenin kaynakları ve ailenin uyum süreci gibi unsurları dikkate alarak planlamaları gerekmektedir (Kaner, 2009; Minuchin, 1974; Turnbull vd., 2013). Dolayısıyla, okul ile aile arasında olumlu bir etkileşim kurulduğunda ve ailenin kaynaştırma katılımı sağlandığında, kaynaştırma uygulamaları aile ve çocuk için faydalı olabilmektedir (Batu ve 
Kurcaali-Ifftar, 2005; Fiedler, Simpson ve Clark, 2007; Sucuoğlu ve Kargın, 2010). Bu doğrultuda, okulların aile-merkezli hizmetler sunmaya önem vermesi gerekmektedir. Bir başka deyişle, okullarda, ebeveynler ve gerektiğinde tüm aile bireyleri çocuklarıla ilgili karar verme süreçlerine ve eğitsel uygulamalara dahil edilmelidirler. Ayrıca, gerek Türkiye'de, gerekse diğer ülkelerde ailelerin özel eğitim ve kaynaştırma sürecine aktif bir şekilde katılmaları konularında yasal olarak gerekli düzenlemeler yapilarak, bu konu yasal bir zorunluluk haline getirilmiştir. Bu yasalarda; ailenin çocuğunun eğitim sürecine ilişkin kararlar alması, özel eğitim hizmetli sunan ekibin bir parçası olması, ailenin katılımının sağlanması için gerekli önlemlerin alınması gerektiği vurgulanmaktadır (Batu, 2008; Berger, 2008; Elkins ve di ğ. 2003; Graungaard ve Skov, 2006; Hallahan, ve Kaufmann, 2009; Odluyurt ve Batu, 2012; Schulz, 1987; Shea ve Bauer, 1991; Smith vd., 2006; Sucuoğlu ve Kargın, 2010; Turnbull ve diğ. 2013).

Ailenin kaynaştırma sürecine uyum gösterebilmesi, çocuklarına uygun bir şekilde destek olabilmesi ve sürece aktif katılımının sağlanabilmesi, bir başka deyişle; aile üyelerinin birer "çalışma ortağı" olarak sürece katılması için ise aileye yönelik çeşitli eğitsel ve psikolojik hizmetler sunulması gerekmektedir (Batu ve Kircaali-İftar, 2005; Hallahan ve Kaufmann, 2009; Iovannone, Dunlap, Huber ve Kincaid, 2003; Sileo ve Prater, 2012; Sucuoğlu ve Kargın, 2010). Ilerleyen bölümlerde makalenin temel konusu bağlamında kaynaştırma öğrencilerinin ailelerine yönelik bu hizmetler incelenecektir.

\subsection{Kaynaştırma Öğrencilerinin Ailelerine Yönelik Eğitsel ve Psikolojik Hizmetler}

Önceki bölümlerde açıklanan aile, çocuk ve toplum arasındaki karşıllklı etkileşime yönelik ekolojik sistem ve aile sistem kuramlarına göre, özel gereksinimli bir bireyin aileye katılımı başta ebeveynler olmak üzere, ailedeki tüm bireyleri etkilemektedir. (Ahioğlu-Lindberg, 2012; Bronfenbrenner, 1979, 1986; Kaner, 2009; Minuchin, 1974; Turnbull vd., 2013; Wehman, 1998). Çocuğun tanı almasıyla birlikte, tüm aile üyeleri için bu yeni duruma uyum sağlamaya çalıştıkları bir süreç başlamaktadır. Ailelerin özel gereksinimli çocuklarının durumuna yönelik tepkileri ailenin özellikleri, içinde yaşadıkları toplumun kültürel özellikleri, aile bireylerinin kişilik özellikleri gibi unsurlara göre değişebilmekle birlikte, ailelerin ortak tepkilerini ve uyum süreçlerini açılayan çeşitli modeller söz konusudur (Ardıç, 2012; Berger, 2008; Chang ve McConkey, 2008; Kaner, 2009; Seligman ve Darling, 2007; Varol, 2007). Bu modellerin belli başlıları aşama modeli (Garguilo, 1985; KüblerRoss, 1969), sürekli üzüntü modeli (Dale, 1996; Kaner, 2009), çaresizlik, güçsüzlük ve anlamsızlık modeli (Dale, 1996; Kaner, 2009) ve ekolojik sistem modeline dayalı olan bütünleyici yaklaşım (Bronfenbrenner, 1979, 1986; Shea ve Bauer, 1991) olarak sıralanabilir. Aşama modeli, bu modeller arasinda en yaygin olan ve en sik kullanılan modeldir. Aşamalar modeli, KüblerRoss (1969) tarafından geliştirilen ve bireylerin yas sürecine yönelik tepkilerini açılayan modele dayalıdır. Aşama modeli temelinde ailelerin çocukları tanı aldıktan sonra geçirdikleri aşamaları şöyle sıralamıştır: (a) şok, inkar, (b) öfke, suçluluk, utanç, (c) pazarlık, (d) depresyon ve umutsuzluk, ve (e) kabul. Aileler çocuklarının durumunu öğrendikten sonra önce şok yaşamaktadırlar. Bu durum onlarda üzüntü, hayal kırıklığı ve çaresizlik gibi duygulara yol açmaktadır. Sıklıkla bu aşamada ailelerin durumu inkar ettikleri görülmektedir. Ailelerin duruma yönelik yaşadıkları öfke, hissettikleri suçluluk ve utanç duygularının ardından pazarlık aşaması gelmektedir. Bu aşamada, pek çok aile gerçekleştirecekleri çeşitli çabalarla çocuklarının durumunun ortadan kalkacağı beklentisindedir. Tanrı ile pazarlık (çocuğumu iyileştirirsen, kendimi dine adayacağım), eğitimcilerle pazarlık (çocuğum düzelirse bir okul yaptıracağım) gibi tepkiler bu aşamaya örnek olarak verilebilir. Bu aşamalar sonrasında durumun değişmediğini gören ve gerçeklerle yüzleşmeye başlayan aile depresyon ve umutsuzluk aşamasını yaşamaktadır. Bu aşamada aile hem kendisi hem de çocuğu için uygun desteklere ulaşırsa çocuğunu özel 
gereksinimiyle birlikte, ailenin bir bireyi olarak kabul eder. Çocuğunun uygun hizmetler alarak, gelebileceği en üst düzeye gelmesi yönünde çaba göstermeye başlar. Uyum aşamasındaki aile ise, çocuğun gelişimi için gerekli planlamaları yapmaya başlar, aynı zamanda kendi bilgi ve becerisini geliştirip çocuğunun eğitim sürecine katkıda bulunur. Bu süreç yaşam boyu devam eden, belirli zamanlarda aşamaların tekrar yaşandığı iç içe geçen ve geri dönüşleri olan bir süreçtir. Örneğin, duruma uyum sağlayan bir aile, belirli dönemlerde tekrar depresyon gibi olumsuz duygu durumlarının yaşandığı evreye geri dönebilmektedir (Ardıç, 2012; Chang ve McConkey, 2008; Garguilo, 1985; Kaner, 2009; Hallahan ve Kaufmann, 2009; Turnbull vd., 2013; Varol, 2007). Ailenin bu sürece en üst düzeyde uyum sağlaması çocuğun tüm eğitim sürecini ve gelişimini olumlu yönde etkilemektedir (Berger, 2008; Hallahan ve Kaufman, 1997; Smith, Gartin, Mudick ve Hilton, 2006; Sucuoğlu ve Kargın, 2010; Varol, 2007). Kaynaştırma ortamlarında da, ailenin yetersizliği kabul etmesi ve duruma uyum sağlamış olması ailenin kaynaştırma sürecine yönelik olumlu tutum sergilemesini ve bu sürece etkin bir şekilde katılımın sağlamaktadır (Dillenburger, Keenan, Doherty, Byrne ve Gallaghen, 2010; Elkins vd., 2003; Shea ve Bauer, 1991; Sileo ve Prater, 2012). Dolayısıyla, ailelere yönelik çeşitli psikolojik ve eğitsel hizmetlerin sunulması ailelerin uyum sürecini kolaylaştırma bağlamında önem taşımaktadır. Nitekim, araştırma sonuçları da, aileye psikolojik ve eğitsel hizmetler sunulduğunda; ailelerin olumsuz duygularında azalma görüldüğünü, sürece daha kolay uyum sağladıklarını, eğitime daha fazla katılım gösterdiklerini ve çocuklarının kaynaştırma ortamlarındaki eğitimlerden daha fazla faydalandıklarını belirtmektedir (Elkins vd., 2003; Hallahan ve Kaufman, 1997; Odluyurt ve Batu, 2012; Öz, 2010; Özen, 2008; Sucuoğlu ve Kargin, 2010; Varol, 2007).

Aileye sunulabilecek psikolojik ve eğitsel hizmetlerin belirlenmesi için, bir başka deyişle ailenin gereksinim duyduğu hizmetin belirlenmesi için öncelikle ailenin çeşitli unsurlar bağlamında değerlendirilmesi gerekmektedir. Bu değerlendirmeyle ailenin; (a) ihtiyaçları (maddi, psikolojik, sosyal vb.), (b) güçlü yanları, (c) yetersizlikleri, (d) beklentileri ve yapısı (aile üyeleri, diğer çocuklarının yaşları, vb.), (e) sosyal çevresi, (f) ebeveyn-çocuk etkileşimi ve aile içi ilişkileri unsurlarına ilişkin detaylı bilgilere ulaşlabilmektedir (Bailey ve Simeonsson, 1998; Cavkaytar ve Özen, 2010; Derguy, Michel, M'Bailara, Roux ve Bouvard, 2015; Lessenberry ve Rehfeldt, 2004; Sucuoğlu, 1995). Ailelerin bu unsurlara yönelik olarak değerlendirilmeleri formal ve/veya informal olarak gerçekleştirilebilmektedir (Bailey ve Simeonsson, 1998; Diken, Topbaş ve Diken, 2009; Fiedler vd., 2007; Öner, 1997; Varol, 2007). Formal değerlendirmeler standartlaştırılmış testler ile gerçekleştirilmektedir. Aile Çocuk İlişkileri Ölçeği, Ebeveyn Davranışını Değerlendirme Ölçeği (Diken, Topbaş ve Diken, 2009), Aile Değerlendirme Ölçeği (Bulut, 1990), Aile Stres Değerlendirme Ölçeği (Kaner, 2002), Çok Yönlü Algilanan Sosyal Destek Ölçeği (Eker ve Arkar, 1995) kullanilabilecek formal değerlendirme araçlarına örnek olarak verilebilir. Görüşme, gözlem, anket ve kontrol listesi gibi belli başlı değerlendirme yöntemleriyle ise informal değerlendirme gerçekleştirilebilir (Bailey ve Simeonsson, 1998; Fiedler vd., 2007; Öner, 1997; Varol, 2007). Aile değerlendirildikten sonra, aileye yönelik hazırlanacak hizmet planı doğrultusunda aileye eğitsel ve psikolojik hizmetlerin sunulması aile-okul işbirliğini güçlendirmektedir. Bu hizmetler ailenin bilgi ve becerilerinin artmasını, ayrıca ailenin psikolojik olarak güçlenmesini sağlayarak, kaynaştırma uygulamasını başarısını arttırmaktadır (Sileo ve Prater, 2012; Hornby,2014; Turnbull vd., 2013).

\subsection{Psikolojik Hizmetler}

Kaynaştırma öğrencilerinin ailelerine gereksinimleri doğrultusunda çeşitli psikolojik hizmetler sunulabilmektedir. $\mathrm{Bu}$ hizmetler, sadece ebeveynleri değil, kardeşler ve büyük anne-babalar olmak üzere tüm aile bireylerini kapsayıcı olmalıdır. Bu hizmetler, psikiyatri, psikoloji ve psikolojik danışmanlık alan uzmanları tarafından sunulabilecek psikiyatri, 
terapi ve/veya psikolojik danışmanlık hizmetleridir (Küçüker, 1993, Sileo ve Prater, 2012; Sommers-Flanagan ve Sommers-Flanagan, 2004; Yıldırım, Hacıhasanoğlu Aşılar ve Karakturt, 2012). Ailenin ihtiyacı doğrultusunda, bazı hizmetler okul içinde psikolojik danışman tarafından sunulabilecekken, bazıları okul dışındaki bir uzmanın desteğini gerektirebilmektedir. Okul psikolojik danışmanı ailelere yönelik stresle baş etme, iletişim becerileri geliştirme gibi konularda bireysel ya da grupla danışmanlık hizmetlerini yürütebilir. Çeşitli konularda (kardeşlerin psikolojik durumları, vb.) bilgilendirici seminerler düzenleyebilir. Aile bireylerinin yaşadıkları psikolojik sorunlar bazen okul dişından bir uzmandan destek almasını gerektirebilecek nitelikte olabilmektedir. Dolayısıyla aile bireylerine okul dişında hizmet sunan psikologlar bireysel ve/veya grup terapisi hizmetleri, psikiyatri uzmanları ise ilaç ve/veya terapi desteği sunabilirler (Baranowski ve Schilmoeller, 1999; Fiedler vd., 2007; Kaufman, 2001; Lessenberry ve Rehfeldt, 2004; Mitchell, 2008; Odluyurt ve Batu, 2012; Seligman, 1991; Varol, 2007; Turnbull vd., 2013).

Kaynaştırma öğrencilerinin ailelerine sunulacak psikolojik hizmetlerin ana temaları ailelerin olası psikolojik ihtiyaçları doğrultusunda şöyle sıralanabilir (Cavkaytar ve Özen, 2010; Elkins ve diğ., 2003; Fiedler vd., 2007; Seligman, 1991): (a) ailelerin yetersizliğe ve/veya kaynaştırma ortamına uyum sürecini kolaylaştırmak ve kaynaştırma ortamında çıkabilecek olası problemleri çözmelerine yardımcı olacak beceriler kazandırmak, (b) depresyon, kaygı gibi olumsuz duygularla ve kriz dönemleriyle başa çıkma becerileri kazandırmak, özgüvenlerini arttırmak, (c) ev ortamında çocuğun gelişimini ve kaynaştırma sürecini olumsuz etkileyecek sorunlara önlem almak, (d) kaynaştırma uygulamasıyla ilgili endişeleri olan, kaynaştırmanın çocuğu için başarı getirmeyeceği gibi olumsuz görüşleri olan ailelere destek sunarak, kaynaştırmaya yönelik olumlu tutum kazandırmak, (e) aile bireyleri arasında olumlu etkileşimi ve iletişim, güçlendirmek, (f) evlilik çatışmalarıyla baş edebilme becerileri kazandırmak, (g) okul çalışanları başta olmak üzere, diğerleriyle iletişim kurma becerileri kazandırmak, (h) etkili ebeveynlik becerileri geliştirmek, (1) ailelerin kendi aralarında sosyal destek grupları kurmalarını teşvik etmek, (i) ailedeki her bireyin birbirini etkilediğini belirten sistem kurmaları bağlamında kardeşlerin ve diğer aile bireylerinin (büyük anne-babalar, vb.) ihtiyaçlarını belirleyip, bu ihtiyaçlara özgü psikolojik hizmetler sunmak.

Psikolojik hizmetlerin kapsamı bazen eğitsel hizmetlerle de örtüşebilmektedir. Çünkü pek çok aile, yetersizlik hakkında bilgi sahibi olmama, problem davranışlarla baş edememe ve çocuğuna nasıl davranacağını bilememe gibi durumlardan dolayı çeşitli olumsuz duygular yaşayabilmektedir (Cavkaytar ve Özen, 2010; Sommers-Flanagan ve Sommers-Flanagan, 2004; Varol, 2007; Turnbull vd., 2013). Ailelerin bu olumsuz duygu durumları kaynaştırmanın başarısını olumsuz yönde etkileyebilmektedir (Sileo ve Prater, 2012; Thawala, Ntinda ve Hlanze, 2015). Bu noktada, aileye eğitsel hizmet sunumu, ailenin duygusal durumunu olumlu etkileyerek, bir tür psikolojik hizmet işlevi görebilmektedir. $\quad \mathrm{Bu}$ bağlamda gerçekleştirilebilecek eğitsel hizmetler bir sonraki bölümde ele alınmıştır.

\subsection{Eğitsel Hizmetler}

Önceki bölümlerde belirtildiği üzere, kaynaştırma öğrencilerinin ailelerine sunulacak hizmetlerden bir tanesi de eğitsel hizmetlerdir. Okul ve/veya ev temelli olarak sunulacak hizmetler, ailenin bilgi ve becerilerini geliştirecek ve kaynaştırma sürecine katkıda bulunacaktır (Batu ve Kırcaali-İftar, 2005; Sucuoğlu ve Kargın, 2010; Varol, 2007). Tüm aile bireylerini kapsayacak şekilde düzenlenmesi gereken eğitsel hizmetler uzmanlık alanları göz önüne alınarak; sınıf öğretmeni, psikolojik danışman, özel eğitim öğretmeni, idareciler ve okul bünyesinde çalışan diğer uzman personel tarafından sunulabilir (Berger, 2008; Cavkaytar ve Özen, 2010; Varol, 2007). Ayrica, okul dişında görev yapan uzmanlardan destek alınabilir. Ailelere yönelik 
eğitsel hizmetler yüz-yüze ve/veya uzaktan yürütülen seminerler, toplantılar ve konferanslar aracılığıyla kuramsal ve uygulamalı eğitimler, bireysel görüşmeler, danışmanlık, ailenin sınıf gözlemi yapması şeklinde olabilir. Ayrıca, ailenin ihtiyaç duyduğu konulara ilişkin yazılı materyallerin aileye verilmesi, ev ziyaretleri, aileleri kitap, dergi ve film gibi kaynaklara yönlendirme şeklinde de gerçekleştirilebilmektedir (Batu ve Kırcaali-İftar, 2005; Berger, 2008; Hallahan ve Kaufmann, 2009; Kaufman, 2001; Odluyurt ve Batu, 2012; Öz, 2005; Sucuoğlu ve Kargın, 2010; Varol, 2007).

Kaynaştırma öğrencilerinin ailelerinin ihtiyaçları değerlendirilerek bu ihtiyaçları doğrultusunda sunulacak eğitsel hizmetlerin ana temaları ise şöyle sıralanabilir (Batu ve Kırcaali-İftar, 2005; Batu, 2012; Cavkaytar ve Özen, 2010; Hallahan ve Kaufmann, 2009; Öz, 2005; Schulz, 1989; Seligman, 1991; Sucuoğlu ve Kargın, 2010): (a) ailelere ebeveynlik rol ve sorumlulukları, gönüllü çalışmalar yapmaları ve yasal haklarını savunmaları için bilgi ve beceri kazandırmak, (b) ailelere çocuklarına çeşitli alanlarda (akademik, özbakım, vb.) eğitim sunabilecek şekilde yetiştirmek, (c) çocuklarının davranış sorunlarıyla baş etmelerine yönelik bilgi ve beceri kazandırmak, (d) ailelere kaynaştırma uygulaması, süreci, okul kuralları, bireyselleştirilmiş eğitim programı (BEP) gibi konular hakkında bilgi sahibi olmaların sağlamak, (e) bir üst kuruma, işe ve mesleğe geçiş konularında bilgi ve beceri kazandırmak, (f) çocuğun gelişimi hakkında aileye bilgi vermek, (g) aileye çocuğunun gelişiminde etkili olacağını düşünülen eğitsel yöntemler ve hizmetler hakkında (örneğin, dil ve konuşma terapisti) bilgi sunmak, (h) kardeşlerin yetersizlikten olumsuz etkilenmemesi için alabilecekleri önlemleri bildirmek, (1) kardeşler ve diğer aile bireylerine (büyük anne-babalar, vb.) gereksinim duydukları konularda bilgi ve beceri kazandırmak.

\section{SONUÇ}

Özel eğitimin temel hedeflerinden bir tanesi olan kaynaştırma uygulamalarının başarılı bir şekilde sürdürülebilmesi, özel gereksinimli bireylerin beceri alanlarında olumlu gelişim göstermelerinde ve toplumsal ortamlara uyum sağlayabilmelerinde oldukça önemlidir. Aile, özel gereksinimli birey ve toplum arasinda sürekli olarak gerçekleşen karşılıklı etkileşim bağlamında, kaynaştırma uygulamasındaki öğrencilerin aileleri ile okul arasındaki işbirliğinin sağlanması ve bu ailelerin kaynaştırma uygulamalarına katılımının sağlanması, kaynaştırma uygulamalarının başarıyla yürütülmesindeki temel etmenlerden bir tanesidir. Nitekim, gerek Türkiye'de, gerekse diğer ülkelerde ailelerin kaynaştırma sürecine aktif bir şekilde katılmaları yasal olarak da bir zorunluluk haline getirilmiştir.

Ailelerin kaynaştırma uygulamalarına aktif olarak katılımlarının sağlanabilmesi için ailelere çeşitli eğitsel ve psikolojik hizmetlerin sunulması gerekmektedir. Ailenin kaynaştırma sürecine uyum gösterebilmesi, okul ve aile arasında güvenli ve nitelikli bir işbirliğinin kurulması ancak bu tür hizmetler sunulduğunda gerçekleşebilecektir. $\mathrm{Bu}$ tür hizmetlerin sunumuyla aileler özel gereksinimli çocuklarına daha etkili bir şekilde destek sunabilecekler ve ayrıca yaşadıkları çeşitli olumsuz duygularla daha kolay baş edebileceklerdir. Dolayısıyla, kaynaştırma uygulamasını yürüten tüm okul çalışanlarının uygulamalarının başarıyla sonuçlanması için ailenin sürece katılımının ön planda tutmaları önemlidir. Aile katılımını sağlamak ve arttırmak için, okul çalışanları uzmanlık alanları doğrultusunda bu makalede de vurgulanan çeşitli eğitsel ve psikolojik hizmetleri sunabilirler. Ayrıca, gerektiğinde okul dışındaki uzmanlardan destek alarak hizmetlerini yürütebilirler. Böylece, aile katılımının sağlandığı bir süreç yürütülerek başarılı bir kaynaştırma uygulaması sağlanabilir.

Aile katılımı ve ailelere sunulacak eğitsel ve psikolojik hizmetlerin önemi doğrultusunda gerek uygulama gerekse ileri araştırmalar 
bağlamında kaynaştırma uygulamalarının başarını arttırabilecek çeşitli öneriler söz konusudur. $\mathrm{Bu}$ doğrultuda uygulama bağlaminda şu öneriler sunulabilir: (a) ailelere yönelik okul içinde ve/veya dışında eğitsel ve psikolojik hizmet sunacak nitelikli uzman personel yetiştirilmesi, (b) kaynaştırma ögrrencilerinin ailelerine uzmanlar tarafından eğitsel ve psikolojik hizmetler verilmesi, (c) okullarda çalışan öğretmenlerin ve idarecilerin kaynaştırma ve aile hizmetleri bağlamında yeterliklerinin arttırılması amaçlı hizmet-öncesi ve hizmet-içi eğitimlerin düzenlenmesi, (d) üniversiteler ve okulların aile katılımı ve ailelere

\section{Kaynakça}

Ahioğlu-Lindberg, N. E. (2012). Çocuk yetiştirme açısından Türkiye'de çocukluğun tarihi. Pamukkale Üniversitesi Ĕ̆itim Fakültesi Dergisi, 31(1), 41-52.

Ardıç, A. ( 2012). Özel gereksinimli çocuk ve aile. A. Cavkaytar (Ed.), Özel eğitimde aile eğitimi ve rehberliği içinde (s.19-52). Ankara: Vize Yayıncılık.

Bailey, D., \& Simeonsson, R. (1998). Assessing needs of families with handicapped infants. The Journal of Special Education, 22(1), 117-127.

Baranowski, M., \& Schilmoeller, G. (1999). Grandparents in the lives of Grand children with disabilities: mothers' perceptions. Education and Treatment of Children, 22(4), 427-446.

Batu, E. S., \& Kırcaali-İftar, G. (2005). Kaynaştırma. Ankara: Kök Yayıncılık.

Batu, E. S. (2012). Yasal dayanaklar ve kaynaştırma. E. S. Batu, A. Çolak ve S. Odluyurt (Eds.), Özel gereksinimli çocukların kaynaştırılması içinde (s. 7-27). Ankara: Vize Yayıncılık.

Batu, E. S. (2008). Kaynaştırma ve destek özel eğitim hizmetleri. İ.H. Diken (Ed.), Özel eğitime gereksinimi olan öğrenciler ve özel eğitim içinde (s. 89-107). Ankara: PEGEM.

Berger, E. H. (2008). Parents as partners in education. Families and schools working together. Upper Saddle River, N.J: Pearson.

Bronfenbrenner, U. (1979). The ecology of human development. Cambridge, MA: Harvard University Press.

Bronfenbrenner, U. (1986). Ecology of the family as a context for human development: Research perspectives. Developmental Psychology, 22, 723-742

Bulut I (1990). Aile değerlendirme ölçeği el kitabı. Ankara, Özgüzeliş Matbaası.

Cavkaytar, A., \& Özen, A (2010). Aile katılımı ve eğitimi. G. Akçamete (Ed.), Genel eğitim okullarında özel gereksinimi olan öğrenciler ve özel eğitim içinde (s. 169-202). Ankara: Kök Yayıncılık.

Chang, M. Y., \& McConkey, R. (2008). The perceptions and experiences of Taiwanese parents who have children with an intellectual disability. International Journal of Disability, Development and Education, 55(1). 27-41.

Dale, N. (1996). Working with Families of Children Weth Special Needs. New York: Rutledge.

Derguy, C., Michel, G., M'Bailara, K, Roux, S., \& Bouvard, M. (2015). Assessing needs in parents of children with autism spectrum disorder: A crucial preliminary step to target relevant issues for support programs. Journal of Intellectual and Developmental Disability, 40(2), 1-11. 
Diken, Ö., Topbaş, S., \& Diken, İ. H. (2009). Ebeveyn davranışını değerlendirme ölçeği (EDDÖ) ile çocuk davranışını değerlendirme ölçeği (ÇDDÖ)'nin geçerlik ve güvenirlik çalışmaları. Ankara Üniversitesi Ĕ̆itim Bilimleri Fakültesi Özel Eğitim Dergisi, 10(2), 41-60.

Dillenburger, K., Keenan, M., Doherty, A., Byrne, T., \& Gallaghen, S. (2010). Living with children diagnosed with autistic spectrum disorder: Parental and Professional views. British Journal of Special Education, 37(1), 13-21.

Eker D., \& Arkar H. (1995). Perceived social support: psychometric properties of the MSPSS in normal and pathological groups in a developing country. Social Psychiatry and Psychiatric Epidemiology, 30, 121-126.

Elkins, J.,VanKraayenoord, C. E., \& Jobling, A. (2003). Parents' attitudes to inclusion of their children with special needs. Journal of Research in Special Education Needs, 3(2), 122-129.

Fiedler, C. R., Simpson, R. L., \& Clark, D. M. (2007). Parents and families of children with disabilities effective school-based support services. Upper Saddle River, NJ: Pearson.

Gargulio, R. M. (1985). Working with parents of exceptional children. A guide for professionals. Boston: Houghton Mifflin Co.

Graungaard, A. H., \& Skov, L. (2006). Why do we need a diagnosis? A qualitative study of parents' experiences, coping and needs, when the new born child is severely disabled. Child: Care, Health and Development, 33(3), 296-307.

Hallahan, D. P., \& Kaufmann, J. M. (2009). Exceptional Learners: Introduction to special education. Boston, MA: Pearson/Allyn \& Bacon.

Hornby, G. (2014). Inclusive Special Education: Evidence-Based Practices for Children with Special Needs and Disabilities. New York: Springer.

Iovannone, R, Dunlap, G, Huber, H., \& Kincaid, D (2003). Effective educational practices for students with autism spectrum disorders. Focus on Autism and Other Developmental Disabilities, 18(3), 4-25.

Kaner, S. (2002). Aile stres değerlendirme ölçeğinin (The questionnaire on resources and stres/F-QRS) ülkemize uyarlama çalışması. Ankara Üniversitesi Ĕ̆itim Bilimleri Dergisi, 34(1-2), 1-10.

Kaner, S. (2009). Aile katılımı ve işbirliği. B. Sucuoğlu (Ed.), Zihin engelliler ve eğitimleri içinde (s. 352405). Ankara: Kök Yayıncilık.

Kargın, T., Acarlar, F., \& Sucuoğlu, B. (2005). Öğretmen, yönetici ve anne babaların kaynaştırma uygulamalarına ilişkin görüşlerinin belirlenmesi. Özel Eğitim Dergisi, 4(2), 55-76.

Kaufman, H. O. (2001). Skills for working with all families. Young Children, 56(4), 81-83.

Kübler-Ross, E. (1969). On death and dying. New York: The Macmillan Company.

Küçüker, S. (1993). Özürlü çocuk ailelerine yönelik psikolojik danışma hizmetleri. Özel Eğitim Dergisi, 1 (3), 23-29.

Lessenberry, B. M., \& Rehfeldt, R. A. (2004). Evaluating stres levels of parents of children with disabilities. Exceptional Children, 70(2), 231-244.

Minuchin, S. (1974). Families and family therapy. Cambridge, MA: Harvard University Press.

Mitchell, W. (2008). The role played by Grand parents in the family support and learning: considerations for mainstream and special schools. Support for Learning, 22(3), 126-135.

Obiakor, F. E., Harris, M., Mutua, K., Rotatori, A., \& Algozzine, B. (2012). Making inclusion work in general education classrooms. Education and Treatment of Children, 35, 477- 490.

Odluyurt, S., \& Batu, E. S. (2012). Kaynaştırmanın başarısını etkileyen faktörler. E. S. Batu, A. Çolak ve S. Odluyurt (Eds.). Özel gereksinimli çocukların kaynaştırlması içinde (s. 27-37). Ankara: Vize Yayincilik. 
Öncül, N, \& Batu, S. (2005). Normal gelişim gösteren çocuk annelerinin kaynaştırma uygulamasına ilişkin görüşleri. Özel Ĕ̆itim Dergisi, 6(2), 37-55.

Öner, N. (1997). Türkiye'de kullanılan psikolojik testler. İstanbul: Boğaziçi Üniversitesi Yayınları.

Öz, A. Ş. (2010). Kaynaştırmada aile katılımı. İ. H. Diken (Ed.), İlköğretimde kaynaştırma. içinde (s. 31-53). Ankara: PEGEM.

Özen, A. (2008). Aile eğitimi. İ.H.Diken (Ed.). Özel eğitime gereksinimi olan öğrenciler ve özel eğitim içinde (s. 109-133). Ankara: PEGEM.

Schulz, J. B. (1987). Parents and proffessionals in special education. Boston: Allyn \& Bacon.

Seligman, M. (1991). The family with a handicapped child. Boston: Allyn \& Bacon.

Seligman, M., \& B. Darling (2007). Ordinary families, special children. New York: The Guilford Press.

Shea, T. M., \& Bauer, A. M. (1991). Parents and teachers of children with exceptionalities. Boston: Allyn \& Bacon.

Sileo, N. M., \& Prater, M. A. (2012). Working with families of children with special needs: Family and Professional partnerships and roles. Boston, MA: Pearson.

Smith, T. E. C., Gartin, B. C., Mudick, N. L., \& Hilton, A. (2006). Families and children with special needs. Upper Saddle River, NJ: Pearson.

Sommers-Flanagan, J., \& Sommers-Flanagan, R. (2004). Counseling and psychothrapy theories incontext and practice: Skills, strategies, and techniques. Hoboken, NJ: John Wiley \& Sons Inc.

Sucuoğlu, B., \& Kargın, T. (2010). İlköğretim'de kaynaştırma uygulamaları. Ankara: Kök Yayıncılık.

Sucuoğlu, B. (1995). Engelli çocuğu olan anne-babaların gereksinimlerinin belirlenmesi. Çocuk ve Gençlik Ruh Sağllğı Dergisi, 2(1), 10-18.

Thwala, S. K.; Ntinda, K., \& Buyisile H.(2015). Lived Experiences of Parents of Children with Disabilities in Swaziland. Journal of Education and Training Studies, 3(4), 206-215.

Turnbull, A., Turnbull, R., Wehmeyer, M. L., \& Shogren, K. A. (2013). Exceptional lives: Special education in today's schools. Upper Saddle River, NJ: Pearson Education, Inc.

Varol, N. (2007). Aile eğitimi. Ankara: Kök Yayıncllık.

Walmsley, J. , \& Mannan, H. (2009). Parents as co-researchers: a participatory action research initiative involving parents of people with intellectual disabilities in Ireland. British Journal of Learning Disabilities, 37(4), 271-276.

Wehman, T. (1998). Family-centered early intervention services: Factors contributing to increased parent involvement and participation. Focus on Autism and Other Developmental Disabilities, 131(2), 80-87.

Yıldııım, A., Hacıhasanoğlu Aşılar, R., \& Karakurt, P. (2012). Engelli çocukların annelerinin ruhsal durumlarının belirlenmesi. İ.Ü.F.N. Hemşirelik Dergisi, 20(3), 200-209. 


\section{EXTENDED SUMMARY}

One of the main objectives of special education is to enable individuals with special needs to receive education in inclusive education environments. Parent-teacher collaboration is quite important for a successful inclusive education practice. Maximum benefit can be provided for individuals with special needs and their parents when parents' involvement in inclusive practices is ensured. Educational and psychological services should be offered to parents to assure their active involvement in inclusive practices. (Sileo and Prater, 2012; Hornby, 2014).

Various psychological services can be provided to the parents of inclusive students based on their needs. These services include psychiatric, therapeutic, and/or psychological counselling services that can be offered by experts in the fields of psychiatrics, psychology, and psychological counselling. The main themes of psychological services that can be offered to the parents of inclusive students based on their possible psychological needs can be listed as follows (Cavkaytar and Özen, 2010; Turnbull et al., 2013): (a) equipping parents with skills that can facilitate their process of adapting to disability and/or inclusive environment and help them to solve the problems likely to emerge in the inclusive environment, (b) providing them with skills of coping with negative emotions, (c) taking precautions against the problems in the home environment that can have a negative effect on children's development and inclusive process, (d) strengthening positive communication among family members, (e) developing effective parenting skills. Educational services (meetings, conferences counseling, etc.) can be provided to the parents of inclusive students by classroom teachers, psychological counsellors, special education teachers, administrators, and other professionals. The main themes of educational services that can be offered to the parents of inclusive students based on their needs can be listed as follows (Batu, 2012; Hallahan and Kaufmann,2009): (a) providing them with knowledge and skills in various matters (e.g. coping with behavioral problems, legal rights), (b) enabling them to be knowledgeable of inclusive practice, inclusive process, individualized education program (IEP), and so on, (c) informing them of educational methods and services that can be influential on their children's development.

To sum up, the importance attached to educational and psychological services that are to be offered to parents can raise the success of inclusive practices by increasing parental involvement. Accordingly, these kinds of services for parents should be extended, and research should be carried out on them. 